\title{
SCREENING FOR INVERDALE (FECX') MUTATION IN BMP15 GENE IN PROLIFIC TURKISH AWASSI SHEEP
}

\author{
Yasemin GEDIK ${ }^{*} *$ \\ ${ }^{1}$ Eskişehir Osmangazi University, Faculty of Agriculture, Department of Animal Science, 26160, Eskişehir, Turkey
}

\begin{abstract}
In the early 1980s, by the determination of the Boorola gene (FecB) in Booroola sheep with high ovulation rate, there has been a great interest for identification of genes that are responsible for prolificacy and their use in breeding programs. The mutation occurred in Bone morphogenetic protein 15 (BMP15), Bone morphogenetic protein-1B (BMPR-1B) and Growth differentiation factor 9 (GDF9) genes have been found to increase the ovulation rate. Additionally some others genes are known to exist based on expressed inheritance patterns although the location of mutations has yet to be found. In the BMP15 gene, with almost the same phenotypic expression eight distinct mutations have been recognized, among them Hanna ( $\mathrm{Fec}^{\mathrm{H}}$ ) and Inverdale (Fec $\mathrm{X}^{\mathrm{I}}$ ) were identified first in Romney sheep in New Zealand. X-linked dominant genes with sterility in homozygous females are the modes of inheritance of the BMP15 gene. A total of 88 prolific Awassi sheep were screened for the presence of the FecX' mutation in the BMP15 gene and Fec ${ }^{1}$ mutation was not found in any of the sheep tested.
\end{abstract}

Keywords: Awassi, BMP15 gene, Inverdale, PCR-RFLP

*Corresponding author: Eskişehir Osmangazi University, Faculty of Agriculture, Department of Animal Science, 26160, Eskişehir, Turkey

E mail: ygedik@ogu.edu.tr (Y.GEDiK)

Yasemin GEDIK $\quad$ (iD) https://orcid.org/0000-0002-3607-1527

Received: August 29, 2021

Accepted: September 07, 2021

Published: October 01, 2021

Cite as: Gedik Y. 2021. Screening for inverdale (FecX') mutation in bmp15 gene in prolific Turkish awash sheep. BSJ Agri, 4(4): $130-132$.

\section{Introduction}

The fact that first time some genes or mutations could be related to the reproductive characteristics of sheep have been started to study with the identification of the Boorala gene in Boorola sheep in the early 1980s. Since then, there has been a growing interest in the determination and utilization of major genes for sheep prolificacy. In sheep, litter size is regulated by ovulation rate, which is further influenced by the quantity of fertilized oocytes. The higher the ovulation rate, the more oocytes are accessible for fertilization during estrous, increasing the chances of larger litters (Drouilhet et al., 2013). Ovulation is a complicated process that varies by species and is regulated by both genetic and environmental factors. The number of oocytes produced during ovulation varies in sheep breeds, ranging from one to ten (Jansson, 2014). Mutations in the genes of superfamily ovary-derived transforming growth factor- $\beta$ (TGF $\beta$ ) considerably enhance the rate of ovulation in sheep (Davis, 2005). They are BMP15, BMPR-1B and GDF9 genes, which code for proteins that are important growth factors and receptors in ovarian follicular growth (Pramod et al., 2013). The effects of these mutations are dominant in nature thus the heterozygous state is sufficient to express as phenotype (Jansson, 2014). Eight distinct mutations (Inverdale, Galway, Belclare, Hanna, Lacaune, Aragonesa, Grivette, Rasa and Olkuska) have been reported in the BMP15 gene in various sheep breeds differ slightly in type and effect (Jansson, 2014).
The Inverdale (FecXI) mutation affecting prolificacy was first identified in one Romney (A281) ewe in an industry flock in New Zealand. Further progeny test and inheritance pattern indicated its location on the $\mathrm{X}$ chromosome (Davis et al., 1991). The heterozygous carriers (I+) show higher ovulation rates at about one unit higher than non-carriers, but homozygous (II) ewes are infertile and show no follicular activity due to ovarian hyperplasia (Davis et al., 1992). The FecXI allele results in a non-conservative replacement of valine with aspartic acid in a highly conserved region of protein at position 31 of the mature peptide due to a single $\mathrm{T}$ to $\mathrm{A}$ (GTC> GAC) mutation in the BMP-15 (Galloway et al., 2000).

Awassi, currently found in more than thirty countries, originated from the Middle East. Awassi has many desirable traits as far as resistance to diseases and parasites, tolerance to extreme temperatures and poor feeding conditions besides its high milk production and growth abilities (Yetiskin and Sen, 2020). This welladopted sheep breed is mainly known for dairy purposes, it is often used for triple purposes, meat, milk, and wool production, in many countries. In Turkey, this breed accounts for $3.5 \%$ of the total sheep population (Aksoy et al., 2019). Birth weight is $4.4 \mathrm{~kg}$ and $3.8 \mathrm{~kg}$, adult weight is $73.9 \mathrm{~kg}$, and $58.2 \mathrm{~kg}$, were reported in Turkey in male and female sheep respectively (Galal et al., 2008). The reproductive parameters such as fertility, twinning rate, lambing rate were found $89.8 \%, 20.3 \%$, and $1.20 \%$ respectively. In $184.3 \pm 2.11$ days of the lactation period, 
milk production accounted for $196.5 \pm 5.60 \mathrm{~kg}$ in ewes (Üstüner and Oğan, 2013). The litter size of Awassi sheep in Turkey was estimated at 1.30-1.40 (Gürsel, 2011). The aim of this study was to identify the FecXI mutation in the BMP-15 gene in the prolific Awassi sheep in Turkey.

\section{Materials and Methods}

\subsection{Animal Materials}

No animals were used as experimental material in this study. A total of eighty-eight blood samples taken from Awassi sheep raised in Şanlıurfa province, which were previously taken for another project, were used as a material in this study (Meydan et al., 2013). The genomic DNA was extracted from the blood samples, which were stored at $-20{ }^{\circ} \mathrm{C}$ until DNA isolation, by standard saltingout extraction method. The quality and quantity of extracted DNA were checked on $1 \%$ agarose gel electrophoresis and spectrophotometer at A260 / A280 $n$ m respectively.

\subsection{PCR Condition and Digestion with the Enzyme}

The PCR-RFLP method reported by Galloway et al. 2000 was used to analyze samples for the FecXI mutation in the BMP15 gene. The forward primer used is to create a recognition site (T\CTAGA) for $X b a$ I restriction enzyme in PCR products from carriers of the mutation but this site is absent in products of non-carriers. Genomic DNA was amplified using the following forward (FecCF1) and reverse (FecCR1) nucleotide sequences; FecCF1: 5'-GAA GTA ACC AGT GTT CCC TCC ACC CTT TTC T-3' and FecCR2: 5'-CAT GAT TGG GAG AAT TGA GAC C-3'. For amplification of $154 \mathrm{bp}$ fragment, a total $25 \mu \mathrm{l}$ of reaction mixture was prepared by adding $10 \mathrm{X}$ PCR buffer, $1.5 \mathrm{mM}$ $\mathrm{MgCl}_{2}, 0.2 \mathrm{mM}$ of each dNTP, $1 \mathrm{pM}$ of each primer, $1 \mathrm{U}$ of Taq polymerase, and 100 ng DNA. The amplification was performed using 35 cycles of $94{ }^{\circ} \mathrm{C}$ for $30 \mathrm{~s}, 60{ }^{\circ} \mathrm{C}$ for $40 \mathrm{~s}$ and $70{ }^{\circ} \mathrm{C}$ for $30 \mathrm{~s}$, followed by $72{ }^{\circ} \mathrm{C}$ for $4 \mathrm{~min}$. After PCR amplification, the $154 \mathrm{bp}$ products were digested with $X b a \mathrm{I}$, and the products were separated by electrophoresis on $2 \%$ agarose gel and visualized with ethidium bromide. Visualization of bands was carried out under ultraviolet transillumination, and the size of the amplified fragments was compared with the $100 \mathrm{bp}$ DNA ladder.

\section{Results}

In the current study, 154 bp DNA fragments containing Inverdale mutation was successfully amplified. These PCR products were subsequently digested with the restriction enzyme $\mathrm{XbaI}$ and separated on a $2 \%$ gel electrophoresis. Since the mutation creates an $X b a I$ recognition site, the heterozygous carrier animals' amplicons are cut to 124 and $30 \mathrm{bp}$. Non-carrier animals lacking the $X b a \mathrm{I}$ recognition site yield a single band of $154 \mathrm{bp}$. After digestion with XbaI, no restriction was detected; all samples gave a single band at $154 \mathrm{bp}$ and showed a negative result for the FecXI mutation (Figure 1).

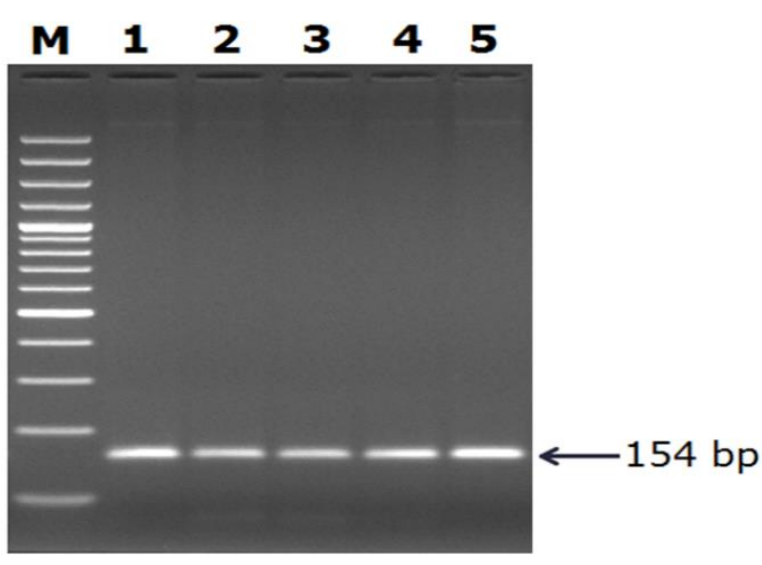

Figure 1. Screening of $F e c X^{I}$ mutation on \%2 agarose gel by PCR- RFLP. Line 1-5 are XbaI digestion products. M; Fermentas GeneRuler ${ }^{\mathrm{TM}} 100$ bp DNA Ladder.

\section{Discussion}

This study was unable to prove the presence of FecX mutation in Turkish Awassi sheep. The result of this study is consistent with previous studies conducted in Chios, Kivircik, Awassi and Imrose breeds by Gürsel et al 2011, and in Sakız breed by Dinçel et al. 2015. They are both reported no inverdale mutation in sheep of Turkey. Also, researches on other mutations related to fecundity have been conducted in different Turkish sheep breeds. A study by Karsli et al., (2011) was conducted to identify FecB, FecXG, FecX ${ }^{\mathrm{H}}$ allele in Kangal and Güney Karaman breeds however did not find existence any of the mutations. Conversely a recent study in a local sheep breed namely Of revealed higher heterozygous genotype frequency $(\mathrm{GA}=0.92)$ in GDF9 gene (GDF91) was linked with increase litter size (Kırıkçı and Çam, 2020).

FecXI mutation was absent not only in Turkish sheep breeds but also in different prolific breeds tested worldwide. Two Indian high prolific breeds Bonpala and Garole were tested negative for this mutation although another gene responsible for increasing litter size FecB was tested positively only in Garole breed (Davis et al., 2002; Roy et al., 2011). A list of breeds from different countries such as Javanese sheep in Indonesia, Thoka sheep in Iceland, Woodlands sheep in New Zealand, Olkuska sheep in Poland, Lacaune sheep in France, Belclare and Cambridge in Ireland (Davis et al., 2002), and Egyptian sheep (Abulyazid et al., 2011) also do not carry FecX ${ }^{I}$ mutation underlying their increased prolificacy. Furthermore, exploration in 21 different high prolific sheep breeds and strains from 13 countries revealed that the reason for their large litter size is unrelated to the FecXI mutation in the BMP15 gene (Davis et al., 2006).

\section{Conclusion}

The FecXI mutation has no effect on the prolificacy of Turkish Awassi sheep were used in this study. Despite the absence of the FecXI mutation, other loci of the BMP15 gene and a major gene for fecundity may provide 


\section{Black Sea Journal of Agriculture}

the genetic explanation for the Awassi sheep's multiple birth traits. Identifying major genes that determine litter size is crucial from an economic standpoint. As a result, a well-thought-out initiative to introduce mutant alleles into Turkish sheep breeds could result in larger litter sizes, which would increase breeder income.

\section{Author Contributions}

All tasks have been done by the single author. The author reviewed and approved the manuscript.

\section{Conflict of Interest}

The authors declare that there is no conflict of interest.

\section{Ethical Consideration}

A retrospective ethics permit is not required for the study due to the experimental material were previously taken for another project (Scientific Research Projects (BAP) of Ankara University, Project No: BAP09B4347007; Project coordinator: Dr. Mustafa Muhip ÖZKAN) and carried out before 2020.

\section{References}

Abulyazid I, Sharada HM, Abdalla MS, Saleh HM, Hassanin WF. 2011. FecX1 gene as a monitor for the production of twins in the Egyptian sheep. Roavs, 1 (4): 217-219.

Aksoy Y, Ugurlu M, Onenc A, Sirin E, Sen U, Ciçek U, Ulutas Z, Kuran M. 2019. Meat production characteristics of Turkish native breeds: II. meat quality, fatty acid, and cholesterol profile of lambs. Arch Anim Breed, 62: 41-48.

Davis GH, Balakrishnan L, Ross IK, Wilson T, Galloway SM, Lumsden BM, Hanrahan JP, Mullen M, Mao XZ, Wang GL. 2006. Investigation of the Booroola ( $\mathrm{FecB}$ ) and Inverdale (FecXI) mutations in 21 prolific breeds and strains of sheep sampled in 13 countries. Anim Reprod Sci, 92 (1-2): 87-96.

Davis GH, Galloway SM, Ross IK, Gregan SM, Ward J, Nimbkar BV, Ghalsasi PM, Nimbkar C, Gray GD, Inounu I. 2002. DNA tests in prolific sheep from eight countries provide new evidence on origin of the Booroola (FecB) mutation. Biol Reprod, 66 (6): 1869-1874.

Davis GH, McEwan JC, Fennessy PF, Dodds KG, Farquhar PA. 1991. Evidence for the presence of a major gene influencing ovulation rate on the $\mathrm{X}$ chromosome of sheep. Biol Reprod, 44 (4): 620-624.

Davis GH, McEwan JC, Fennessy PF, Dodds KG, McNatty KP, Wai-Sum O. 1992. Infertility due to bilateral ovarian hypoplasia in sheep homozygous (FecX1 FecX1) for the Inverdale prolificacy gene located on the $\mathrm{X}$ chromosome. Biol Reprod, 46 (4): 636-640.

Davis GH. 2005. Major genes affecting ovulation rate in sheep.
Genet Sel Evol, 37: 11-23.

Dinçel D, Ardıçlı S, Soyudal B, Er M, Alpay F, Şamlı H, Balcı F. 2015. Analysis of FecB, BMP15 and CAST gene mutations in Sakiz sheep. Kafkas Univ Vet Fak Derg, 21 (4): 483-488.

Drouilhet L, Mansanet C, Sarry J, Tabet K, Bardou P. 2013. The Highly prolific phenotype of Lacaune Sheep is associated with an ectopic expression of the B4GALNT2 gene within the ovary. PLoS Genet, 9 (9): 1-12.

Galal S, Gürsoy O, Shaat I. 2008. Awassi sheep as a genetic resource and efforts for their genetic improvement-A review. Small Rumin Res, 79: 99-108.

Galloway SM, McNatty KP, Cambridge LM, Laitinen MP, Juengel JL, Jokiranta TS, McLaren RJ, Luiro K, Dodds KG, Montgomery GW. 2000. Mutations in an oocyte-derived growth factor gene (BMP15) cause increased ovulation rate and infertility in a dosage-sensitive manner. Nat Genet, 25 (3): 279-283.

Gürsel E, Akış I, Durak H, Mengi A, Öztabak K. 2011. Determination of BMP-15, BMPR-1B and GDF-9 gene mutations of the indigenous sheep breeds in Turkey. Kafkas Univ Vet Fak Derg, 17 (5): 725-729.

Jansson T. 2014. Genes involved in ovulation rate and litter size in sheep. B.S thesis, Swedish University of Agricultural Sciences Faculty of Veterinary Medicine and Animal Science, Uppsala, pp 19.

Karsh T, Şahin E, Karslı BA, Eren MG, Balcıoğlu MS. 2011. Kangal ve Güney Karaman koyunlarinda FecB FecXG, FecXH allellerinin PCR-RFLP yöntemi kullanılarak araştırılması. Lalahan Hay Araşt Enst Der, 51 (2): 71-80

Kırıkçı, K, Çam MA. 2020. Türkiye yöresel yeni koyun tipi of koyunlarında GDF9 (FecG1) gen polimorfizmin PCR-RFLP yöntemi ile Araştırılması. MJAVL, 10 (2): 98-102.

Meydan H, Ozkan MM, Yildiz MA, Goldmann W. 2013. Novel polymorphisms in ovine prion protein gene. Anim Genet, 44(5):588-591.

Pramod RK, Sharma SK, Kumar R, Rajan A. 2013. Genetics of ovulation rate in farm animals.Vet.World, 6 (11): 833-838.

Roy J, Polley S, De S, Mukherjee A, Batabyal S, Pan S, Brahma B, Datta TK, Goswami SL. 2011. Polymorphism of fecundity genes (FecB, FecX, and FecG) in the Indian Bonpala sheep.Anim Biotechnol, 22 (3): 151-162.

Üstüner H, Oğan MM. 2013. Main productive performance of Awassi sheep in the Central Anatolian Region of Turkey. Turkish J Vet Anim Sci, 37 (3): 271-276.

Yetisgin OS, Sen U. 2020. Resilience to drought in semi-desert sheep: Effects of water restriction during pregnancy on placental efficiency in the Awassi breed. Anim Sci J, 91: e13494. 